\title{
KEWENANGAN PEMERINTAH DALAM PENGENDALIAN PENDUDUK PENDATANG DENGAN MELIBATKAN DESA PAKRAMAN ${ }^{1}$
}

\author{
Oleh : \\ Anak Agung Istri Ari Atu Dewi
}

\begin{abstract}
Population has been a complex problem in development these days, especially in Denpasar, rapid population growth with limited support and capacity is the main problem. In conncetion to that, this research is aiming to find out 2 (two) things: first, to know juridical regulation for migrants in Denpasar. Second, to know about the involment of Pakraman Village (Customary Village) in managing migrants. This research uses statute approach. According to research it is concluded that: first, to anticipate rapid population growth or manage migrants in legal area of Denpasar, Government of Denpasar bases its authority in 1945 Constitution of the Repulic of Indonesia, Law Number 23 of 2014, Law Number 23 of 2006 as amended in Law Number 24 of 2013, Local Government of Bali Act Number 10 of 1998, Local Government of Bali Act Number 3 of 2001, Local Government Act Number 5 of 2014 concerning Amendement of Local Government Act of Denpasar Number 6 of 1996 concerning Framework Implementation for Population Registration in Population Management Information System, Mayor Act Number 593 of 2000 concerning Migrants Management. This act is also amended to Mayor Act Number 610 of 2002 concerning Amandement of Mayor Act Number 539 of 2000. Second, the involment of Pakraman village in managing migrants in Denpasar is regulated under the said Local Government Act, Mayor Act and Agreement between Government with Pakraman Village in Denpasar. The regulation is clear, giving the village authority to manage migrants in accordance to local customary law in force (awig-awig). This Research recommends that a clearer regulation in awig-awig and implementation of policies concerning migrants management is needed.
\end{abstract}

Keywords: Authority, Migrants, Pakraman Village

\begin{abstract}
Abstrak
Masalah kependudukan telah menjadi persoalan yang sangat kompleks dalam perkembangan dewasa ini, khususnya di Kota Denpasar, pertumbuhan penduduk sangat pesat dengan daya dukung serta daya tampung sangat terbatas menjadi persoalan utama. Berhubungan dengan hal tersebut maka dilakukan penelitian untuk mengetahui 2 (dua) hal yaitu : pertama, untuk mengetahui pengaturan secara yuridis penduduk pendatang di Kota Denpasar. Kedua, untuk mengetahui mengenai keterlibatan desa pakraman dalam pengendalian penduduk pendatang. Pendekatan yang digunakan adalah pendekatan peraturan perundang-undangan (statue approach). Berdasarkan hasil penelitian dapat disimpulkan sebagai

1 Penulis adalah Dosen Fakultas Hukum Universitas Udayana Denpasar Bali, email : ariatudewi@ gmail.com
\end{abstract}


berikut: pertama, untuk mengantisipasi ledakan kependudukan ataupun pengendalian penduduk pendatang di wilayah hukum Kota Denpasar, Pemerintah Kota Denpasar mendasarkan kewenangannya dengan UUD Negara Republik Indonesia Tahun 1945, UU 23 Tahun 2014, UU 23 Tahun 2006 sebagaimana telah diubah dengan UU Nomor 24 Tahun 2013, Perda Provinsi Bali 10 Tahun 1998, Perda Provinsi Bali 3 Tahun 2001, Perda 5 Tahun 2014 tentang Perubahan atas Peraturan Daerah Kota Denpasar Nomor 6 Tahun 1996 tentang Penyelenggaraan Pendaftaran Penduduk dalam Kerangka Sistem Informasi manajemen Kependudukan (SIMDUK), Keputusan Walikota Nomor 593 Taun 2000 tentang Penertiban Penduduk Pendatang. Keputusan ini juga terjadi perubahan yaitu Keputusan Walikota Denpasar Nomor 610 Tahun 2002 tentang Perubahan Keputusan Walikota Denpasar Nomor 539 Tahun 2000. Kedua, mengenai pelibatan Desa Pakraman dalam pengendalian penduduk pendatang di Kota Denpasar diatur secara jelas di dalam Perda, Keputusan Walikota dan Kesepakatan Kerja sama antara Pihak Kedinasan dengan Pihak Desa Pakraman di Kota Denpasar. Pengaturan secara jelas keterlibatan Desa Pakraman, memberikan otoritas kepada Desa Pakraman dalam pengendalian Penduduk pendatang sesuai dengan awig-awig desa pakraman setempat. Rekomendasi penelitian adalah perlu adanya pengaturan lebih jelas dalam awig-awig desa pakraman dan penerapan kebijakan-kebijakan hukum yang sungguh-sungguh terkait dengan pengendalian penduduk pendatang.

\section{Kata kunci : Kewenangan, Penduduk Pendatang, Desa Pakraman.}

\section{PENDAHULUAN}

Pariwisata telah banyak memberikan kontribusi bagi perkembangan masyarakat Bali secara menyeluruh. Namun meski disadari sebagai sebuah industri yang mampu menghidupi sebagian besar masyarakat, dampak negatif pariwisata pun cukup banyak. Keberhasilan pariwisata di Bali di akui menjadi sebab bertambahnya migrasi ke Bali, salah satu dampak yang ditimbulkan dari keberhasilan pariwisata adalah masalah kependudukan. Sebagaimana dikatakan Pitana bahwa masalah kependudukan dapat menimbulkan dampak sekunder yang berantai seperti pengangguran, gelandangan dan pengemis, prostitusi, penyalahgunaan obat terlarang, tindakan kriminal atau berbagai penyakit sosial lainnya. Di berbagai tempat masalah kependudukan dapat menimbulkan konflik sosial antar ras, suku, agama ataupun masalah ekonomi. Apabila masalah kependudukan ini tidak dikelola dengan baik akan berdampak negatif bagi kelangsungan pariwisata di Bali.

Menurut Pitana ${ }^{3}$, masalah kependudukan telah menjadi persoalan yang sangat kompleks dalam perkembangan pariwisata di Kuta. Hal ini sangat dirasakan oleh semua lapisan masyarakat di Kuta 3 Pitana, I Gde, 2000, Kuta Cermin Retak Pariwisata Bali, Upada Sastra. 
baik kalangan birokrat maupun para usahawan yang bergerak di bidang ekonomi. Masalah kependudukan juga merupakan pusat perhatian, dimana dikatakan bahwa Bali sebagai tempat aktivitas masyarakat nasional maupun internasional baik dalam kegiatan ekonomi,pemerintahan,pendidikan dan kebudayaan akan menimbulkan suatu permasalahan yang sangat strategis yaitu "masalah kependudukan". Masalah kependudukan ini tidak dapat dipandang sebelah mata karena masalah kependudukan merupakan masalah yang multi dimensional dan multi effect.

Sebagai gambaran awal, berdasarkan data BAPPEDA provinsi Bali bahwa laju Pertumbuhan Penduduk Bali Mencengangkan. Laju pertumbuhan penduduk Bali dalam 5 (lima)tahunterakhirrentang2010-2015 sangat pesat. Pada tahun 2010 jumlah penduduk Bali mencapai 3.890 .800 jiwa, Tahun 2011 mencapai 3.957.600 jiwa, tahun 2012 mencapai 4.007.200 jiwa, tahun 2013 mencapai 4.056.300 jiwa, tahun 2014 mencapai 4.104.900 jiwa dan 2015 mencapai 4,125.800 jiwa ${ }^{4}$. Data ini menunjukkan bahwa 5 (lima) tahun terakhir penduduk Bali semakin meningkat dengan mencapai 1.17 persen pada tahun 2015 .

Selanjutnya data yang diungkap Bali Post bahwa pertambahan penduduk pendatang di Denpasar setiap tahunnya terus meningkat. Bahkan, laju pertambahan penduduk

4 www.bappeda.baliprov.go.id, diakses tanggal 18 Oktober 2016. pendatang mengalahkan pertumbuhan penduduk tetap. Data terbaru menyebutkan pertumbuhan penduduk pendatang di Denpasar mencapai 0,12 persen per tahun, sedangkan pertumbuhan penduduk tetap hanya 0,02 persen. Jumlah penduduk pendatang yang menuju Denpasar per tahunnya mencapai 4.000 orang. Jika rasio pertumbuhan ini terus terpolakan maka marginalisasi penduduk lokal sangat terbuka.

Selanjutnya berdasarkan data dari Badan Pusat Statistik Kota Denpasar, laju pertumbuhan penduduk setiap tahunnya meningkat. Pada tahun 2015 mencapai 1.97 persen dengan jumlah penduduk mencapai 880.600 jiwa. Laju pertumbuhan dimaksud ada dalam matrik:

Laju pertumbuhan penduduk di Kota Denpasar berdasarkan data BPS Kota menunjukkan bahwa laju pertumbuhan penduduk di Kota Denpasar melebihi laju pertumbuhan penduduk di provinsi Bali. Ini menunjukkan bahwa di Kota Denpasar pertambahan penduduk sangat sulit dikendalikan sehingga memerlukan strategi untuk mengendalikan laju pertumbuhan penduduk.

Berdasarkan gambaran tersebut, jika kehadiran urban ke Bali khususnya ke kota denpasar yang tidak terkontrol sangat potensial menimbulkan gesekan tata ruang serta lahirnya kantongkantong kemiskinan di tengah kota, tidak hanya itu degradasi budaya juga terbuka lebar. 
Jumlah dan Laju Pertumbuhan Penduduk Kota Denpasar, 2001-2015

Tahun/ Jumlah Penduduk

Laju Pertumbuhan Penduduk

\begin{tabular}{crr}
\hline \hline$(1)$ & $(2)$ & $(3)$ \\
\hline \hline 2001 & 532921 & 36,57 \\
2002 & 555174 & 3,20 \\
2003 & 578201 & 4,15 \\
2004 & 602018 & 4,12 \\
2005 & 626641 & 4,09 \\
2006 & 652110 & 4,06 \\
2007 & 678193 & 4,00 \\
2008 & 705115 & 3,97 \\
2009 & 732897 & 3,94 \\
2010 & 788589 & 7,60 \\
2011 & 810900 & 2,83 \\
2012 & 828900 & 2,22 \\
2013 & 846200 & 2,09 \\
2014 & 863600 & 2,06 \\
2015 & 880600 & $\mathbf{1 , 9 7}$ \\
\hline
\end{tabular}

Sumber : Badan Pusat Statistik Kota Denpasar ${ }^{5}$

Di sisi lain, salah satu lembaga adat yang merupakan wadah masyarakat adat di Bali dalam membina kehidupannya yang sosial religius adalah desa pakraman. Dalam kaitannya tersebut desa pakraman mempunyai otonomi baik dalam menetapkan aturan hukum yang berlaku di lingkungan wilayahnya (awig-awig) termasuk mengatur masalah kependudukan baik sebagai krama desa dan krama tamiu (penduduk pendatang). Desa pakraman juga mempunyai otonomi dalam menyelenggarakan organisasinya yang sosial relegius, serta berwenang menyelesaikan permasalahan hukum khususnya

5 http://denpasarkota.bps.go.id/, diakses tanggal 18 Oktober 2016. permasalahan hukum adat yang terjadi di wilayahnya. Permasalahan hukum adat tersebut dapat berupa pelanggaran hukum adat maupun sengketa adat. Mengingat pentingnya peran desa pakraman dalam penataan kependudukan khususnya penduduk yang ada di wilayahnya, maka dari itu pelibatan desa pakraman dalam pengendalian penduduk pendatang perlu mendapat perhatian yang serius, sebab dalam pelaksanaan kebijakan pemerintah dibidang kependudukan, (pengendalian penduduk), sebagai ujung tombak yang langsung berhadapan dengan penduduk pendatang adalah pemerintahan desa. Pemerintahan desa di Bali melingkupi Desa Dinas dan Desa Pakraman. Masing-masing Desa 
tersebut mempunyai fungsi dan kewenangan tersendiri dalam pengaturan danpengendalianpenduduk pendatang. Dengan demikian, penelitian ini penting untuk dilakukan dalam rangka untuk menjawab keterlibatan desa pakraman dalam pengendalian penduduk pendatang di Kota Denpasar. Hal ini penting untuk diketahui karena: pertama, bahwa desa pakraman sebagai salah satu bentuk desa yang ada di Bali yang juga mempunyai kewenangan mengurus penduduk pendatang sehingga pelibatan desa pakraman penting agar tidak terjadi konflik kewenangan dalam pelaksanaan tugas. kedua, desa pakraman berkepentingan untuk dilibatkan karena menyangkut penduduk yang memasuki dan hidup di wilayahnya.

Tujuan Penelitian adalah untuk mengetahui kewenangan Pemerintah Daerah Kota Denpasar dalam Pengendalian Penduduk Pendatang dan untuk mengetahui bentuk-bentuk keterlibatan desa pakraman dalam pengendalian penduduk pendatang.

Berdasarkan paparan di atas maka dipandang perlu dilakukan penelitian dan kajian ilmiah terkait dengan kewenangan Pemerintah Kota Denpasar dalam pengendalian penduduk pendatang dan bentuk keterlibatan Desa Pakraman dalam Pengendalian Penduduk Pendatang.

\section{METODE PENELITIAN}

Menurut Morris L. Cohen dan Kent C. Olson mengemukakan bahwa "Legal research is an essential component of legal practice. It is the process of finding the law that governs an activity and materials that explain or analyze that law". ${ }^{6}$ Dalam penelitian ini digunakan Jenis penelitian normatif, penelitian ini digunakan untuk membedah permasalahan yang terkait dengan kewenangan Pemerintah Daerah dalam pengendalian penduduk pendatang yang fokus kajian pada kebijakan-kebijakan hukum Pemerintah Kota Denpasar dalam pengendalian penduduk pendatang dan mengkaji juga mengenai bentukbentuk keterlibatan desa pakraman dalam pengendalian penduduk pendatang tersebut.

Sumber bahan hukum yang digunakan adalah bahan hukum primer dan dahan hukum sekunder. Bahan hukum primer mencakup UUD NRI Tahun 1945, UU 24 tahun 2013 tentang Perubahan Atas UndangUndang Nomor 23 Tahun 2006 Tentang Administrasi Kependudukan, Perda 10 Tahun 1998 tentang Pengendalian Kependudukan Dalam Wilayah Propinsi Daerah Tingkat I Bali, Perda Kota Denpasar 5 Tahun 2014 tentang Perubahan atas Peraturan Daerah Kota Denpasar Nomor 6 Tahun 1996 tentang Penyelenggaraan Pendaftaran

6 Morris L. Cohen dan kent C. Olson, 2000, Legal Research In A Nutshell, Seventh Edition, ST. Paul, Minn, West Group, hlm. 1. 
Penduduk dalam Kerangka Sistem Informasi manajemen Kependudukan (SIMDUK), SK Walikota Denpasar Nomor 593 Tahun 2000 tentang Penertiban Penduduk Pendatang di Kota Denpasar, SK Walikota Denpasar Nomor 610 Tahun 2002 tentang Perubahan Keputusan Walikota Denpasar nomor 539 Tahun 2000 Tentang Penertiban Penduduk Pendatang, SK Walikota Denpasar Nomor 585 Tahun 2002 tentang Perubahan Lampiran tentang Keputusan Walikota Denpasar Tanggal 13 Desember 2001 Nomor 1002 Tahun 2001 tentang Standarisasi Pungutan Desa/ Sumbangan Kelurahan di Kota Denpasar. Bahan hukum sekunder melingkupi bahan-bahan penunjang baik itu berupa buku, jurnal dan bahan informasi lainnya. Selanjutnya Bahan hukum yang telah terkumpul baik diolah dan dianalisis secara kualitatif dengan menggunakan interpretasi hukum. Interpretasi yang digunakan adalah terkait dengan hermeneutika hukum. ${ }^{7}$ Hermeneutika hukum pada intinya adalah metode interpretasi atas teks hukum, yang menampilkan segi tersurat yakni bunyi teks hukum dan segi tersirat yang merupakan gagasan yang ada di belakang teks hukum itu. ${ }^{8}$

7 Lihat Soelistyowati Irianto, "Memperkenalkan Studi Sosiolegal ...", Ibid., hlm. 181

8 Diadaptasi dari Gede Marhaendra Wija Atmaja, "Politik Pluralisme Hukum dalam Pengakuan Kesatuan Masyarakat Hukum Adat dengan Peraturan Daerah", Disertasi Doktor, Program Doktor Ilmu Hukum Fakultas Hukum Universitas Brawijaya, Malang, 2012, hlm. 17-18.
Keseluruhan hasil analisis, selanjutnya disajikan secara deskriptif yaitu dengan memaparkan secara lengkap segala persoalan yang terkait dengan masalah yang diteliti disertai dengan memberikan ulasan-ulasan secara kritis

\section{HASIL DAN PEMBAHASAN \\ a. Kewenangan Pemerintah Kota Denpasar Dalam Pengendalian Penduduk Pendatang}

Pemahaman Kewenangan dapat dilihat dari beberapa pendapat para sarjana, diantaranya P. Nicolai, menyebut bahwa kewenangan merupakan kemampuan untuk melakukan suatu tindakan hukum tertentu. Tindakan tersebut dimaksudkan untuk menimbulkan akibat-akibat hukum, dan mencakup mengenai timbul dan lenyapnya akibat hukum. Selanjutnya dalam istilah Belanda disebut "Het vermogen tot het verrichten van bepaalde rechtshandelingn (handeling die op rechtsgevoleg gericht zijn en dus ertoe strekken dat bepaalde rechtsgovelgen onstaan of teniet gaan). Een recht houdt in de (rechten gegeven) aanspraak op het verrichten van een handeling door een ander. Een plicht impliceert een verplichting om een bepaalde handeling te verrichten of na te laten". ${ }^{9}$ Philipus M. Hadjon juga menyatakan bahwa kewenangan

9 Ridwan HR, 2006, Hukum Administrasi Negara, PT. Raja Grafindo Persada, Jakarta, hlm.102. 
dalam membuat suatu keputusan dapat diperoleh dengan 2 cara, yaitu dengan atribusi dan delegasi. ${ }^{10}$ Menurut Indroharto $^{11}$ menyatakan bahwa wewenang diperoleh secara atribusi, delegasi dan mandat. Lukman Hakim ${ }^{12}$ juga menyatakan bahwa sumber kewenangan ada tiga yaitu atribusi, delegasi dan mandat.

Merujuk pendapat P. Nicolai bahwa kewenangan itu dapat diartikan sebagai kemampuan untuk melakukan tindakan hukum tertentu (yaitu tindakan-tindakan yang dimaksudkan untuk menimbulkan akibat-akibat hukum, dan mencakup mengenai timbul dan lenyapnya akibat hukum) ${ }^{13}$. Pemahaman yang demikian menempatkan pemahaman pada bahwa hak berisi kebebasan untuk melakukan atau tidak melakukan tindakan tertentu atau menuntut pihak lain untuk melakukan tindakan tertentu, sedangkan kewajiban memuat keharusan untuk melakukan tindakan tertentu. Mendasarkan pada pendapat P Nicolai, bahwa Pemerintah

10 Philipus M. Hadjon, et.al, 2011, Pengantar Hukum Administrasi Indonesia, Introduction to the Indonesian Administrative law, Gadjah Mada University Press, Yogyakarta, hlm. 130.

11 Indroharto, 1993, Usaha memahami UndangUndang tentang Peradilan Tata Usaha Negara, Pustaka Harapan, Jakarta, hlm.90.

12 Lukman Hakim, 2012, Filosofi Kewenangan Organ Lembaga Daerah Perspektif Teori otonomi \& Desentralisasi dalam Penyelengaraan Pemerintahan Negara Hukum dan Kesatuan, Setara Press Malang, hlm. 126. Lihart juga Jum Anggriani, 2012, "Hukum Adminsitrasi Negara", Graha Ilmu, Yogyakarta, hlm. 92

13 Ridwan HR, 2006, Ibid.
Kota Denpasar berwenang dalam melakukan tindakan yaitu dalam konteks melakukan pengendalian penduduk pendatang.

Dalam konteks sosiologis, sebagaimana data yang di tampilkan pada latar belakang yang menunjukkan bahwa setiap tahu laju pertumbuhan penduduk di Kota Denpasar semakin meningkat, bahkan melebihi laju pertumbuhan Provinsi Bali. Meningkatnya laju pertumbuhan penduduk di Kota Denpasar yang mencapai 1.97 dengan daya tampung yang terbatas berimplikasi terhadap ledakan penduduk yang memicu problem-problem sosial, seperti kemiskinan, kejahatan dan sebagainya.

Kota Denpasar sebagai tempat aktivitas masyarakat nasional maupun internasional baik dalam kegiatan ekonomi, pemerintahan, pendidikan dan kebudayaan akan berdampak menimbulkan suatu permasalahan yang sangat kompleks, diantaranya adalah masalah kependudukan. Masalah kependudukan ini tidak dapat dipandang sebelah mata karena masalah kependudukan merupakan masalah yang dimensional dan multi efek. Penduduk yang menjadi sumber daya manusia akan menjadi modal atau pendukung pembangunan apabila memiliki keterampilan dan kualitas yang baik. Penduduk yang banyak dengan kualitas yang rendah akan menjadi beban pembangunan. Kehadiran Urbanisasi ke Kota 
Denpasar yang tidak terkontrol berpotensi menimbulkan gesekan tata ruang, timbulnya berbagai macam permasalahan-permasalahan sosial, lahirnya kantong-kantong kemiskinan di tengah-tengah kota serta degradasi budaya yang terbuka lebar. Dengan demikian, perlu ada upaya dan komitmen dari pemerintah Kota Denpasar agar kemiskinan dapat di tanggulangi. Oleh sebab itu, Pemerintah Kota Denpasar perlu mengantisipasimengenaipengendalian kependudukan melalui penertiban penduduk, khususnya meminimalisasi penduduk pendatang. Untuk itu perlu dilakukan strategi dari Pemerintah Kota yaitu dengan merumuskan kebijakan-kebijakan pemerintah di bidang kependudukan.

Dalam melakukan pengendalian penduduk pendatang, Pemerintah Kota Denpasar mendasarkan pada kewenangannya sesuai dengan Undang-Undang Dasar Negara Republik Indonesia Tahun 1945 mengatur mengenai penduduk yaitu dalam Pasal 26 ayat (2) yang berbunyi "Penduduk ialah warga negara Indonesia dan orang asing yang bertempat tinggal di Indonesia". Pada ayat (3) dinyatakan "Hal-Hal mengenai warga negara dan penduduk diatur dengan Undang-Undang”. Dalam pemahaman UUD NRI Tahun 1945 ini adalah ada dasar pengaturan penduduk dalam konteks ini penduduk pendatang. Dalam Undang-undang Nomor 23 Tahun 2014 tentang Pemerintahan
Daerah juga jelas diatur tentang Kependudukan yaitu dalam Pasal 12 Ayat (2) huruf F yang menyatakan bahwa dalam bidang Administrasi Kependudukan dan Pencatatan Sipil merupakan urusan wajib. Pengaturan Administrasi Kependudukan juga dapat dilihat dalam lampiran huruf $\mathrm{L}$ khususnya dalam bidang Administrasi Kependudukan dan Pencatatan Sipil, dimana kewenangan Kabupaten/ Kota adalah pelayanan pendaftaran penduduk. Mendasarkan pada Pasal di atas dapat dipahami bahwa ada kewenangan dari Kota Denpasar untuk mengatur administrasi kependudukan termasuk di dalamnya di dalamnya pengaturan penduduk pendatang. Selanjutnya secara materiil pengaturan penduduk pendatang juga dapat dilihat dalam Undang-undang Nomor 24 Tahun 2013 Tentang Perubahan atas Undang-Undang Nomor 23 Tahun 2006 tentang Administrasi Kependudukan. Dalam Undang-undang Nomor 24 Tahun 2013, pengaturan mengenai penduduk terdapat dalam Pasal 1 angka 2 yang menyatakan "Penduduk adalah Warga Negara Indonesia dan Orang Asing yang bertempat tinggal di Indonesia". Rumusan dalam Pasal 1 angka 2 Undang-undang Nomor 24 Tahun 2013 ini sama dengan rumusan yang terdapat dalam UUD 1945. Mengenai pendaftaran penduduk terdapat dalam Pasal 1 angka 10 yang menyatakan bahwa Pendaftaran Penduduk merupakan pencatatan biodata Penduduk, 
pelaporan Peristiwa Kependudukan, pendataan serta penerbitan Dokumen Kependudukan yang berupa kartu identitas ataupun surat keterangan kependudukan. Selanjutnya dalam Pasal 1 angka 11 dengan jelas mengatur peristiwa kependudukan yang di dalamnya termasuk penduduk pendatang. Selanjutnya norma pasal 1 angka 11 UU Adminduk menyatakan "Peristiwa Kependudukan merupakan kejadian yang dialami Penduduk dan harus dilaporkan karena membawa akibat terhadap penerbitan atau perubahan Kartu Keluarga, Kartu Tanda Penduduk.

Perlu juga dipahami bahwa perubahan UU Nomor 23 Tahun 2006 tidak serta merta menggantikan UU Nomor 23 Tahun 2006, melainkan ada beberapa Pasal dalam UU 23 Tahun 2006 yang berubah. Dengan demikian ada ketentuan-ketentuan pada UU 23 Tahun 2006 masih berlaku.

Di Dalam kaitannya dengan pendaftaran penduduk, dalam UU 23 Tahun 2006 diatur dalam Bab IV mengenai Pendaftaran Penduduk. Khusus mengenai penduduk pendatang diatur dalam Bab IV bagian kedua Paragraf 2 tentang Pindah Datang Penduduk. Dalam Pasal 6 Undang-Undang Nomor 23 Tahun 2006 memberikan kewenangan kepada pemerintah provinsi untuk menyelenggarakan administrasi kependudukan. Selanjutnya dalam Pasal7Undang-UndangNomor23tahun 2006 juga memberikan kewenangan pada pemerintah Kabupaten/Kota untuk menyelenggarakan administrasi kependudukan. Mengenai teknis dan tata cara pendaftaran penduduk diatur dalam Peraturan Presiden Nomor 25 Tahun 2008 yaitu diatur dalam Pasal 21 mengenai Pendaftaran Pindah Datang Penduduk WNI.

Dalam tataran peraturan lokal yaitu Peraturan Daerah Propinsi Bali Nomor 10 Tahun 1998 tentang Pengendalian Kependudukan Dalam Wilayah Propinsi Daerah Tingkat I Bali, secara jelas mengatur mengenai penduduk pendatang yang terdapat dalam Pasal 1 huruf q yaitu "Pendatang baru adalah penduduk yang datang akibat mutasi kepindahan dari luar daerah dan telah memenuhi syaratsyarat yang telah ditetapkan oleh Gubernur Kepala Daerah". Selain itu dalam Pasal 1 huruf $p$ juga diatur mengenai penduduk sementara yaitu "penduduk yang tidak menetap yang berada dalam wilayah daerah dengan ijin tinggal terbatas". Pasal 1 huruf $r$ mengaturmengenaipendudukmusiman yaitu "setiap orang Indonesia yang datang dari luar daerah dan bertempat tinggal tidak terus-menerus". Peraturan Daerah Nomor 10 tahun 1998 ini diarahkan pada pengendalian kuantitas dan kualitas penduduk serta mobilitas penduduk daerah. Pernyataan tersebut sebagaimana terdapat dalam Pasal 8 yang menegaskan bahwa Gubernur berwenang membentuk aturan tentang pengendalian penduduk pendatang yang berdasarkan keseimbangan 
daya dukung dan daya tampung. Selanjutnya dalam Pasal 9 menegaskan mengenai kualitas penduduk, dimana Gubernur menetapkan kebijakan penyelenggaraan pengembangan kualitas penduduk dengan memperhatikan nilai-nilai agama, etika dan social budaya. Dalam Pasal 10 juga ditegaskan mengenai mobilitas pendudukyaitubahwa adakewenangan Kepala Daerah untuk menetapkan kebijakan terkait dengan pengarahan mobilitas dan penyebaran penduduk yang optimal yang berdasarkan pada daya dukung dan daya tampung.

Dengan demikian dapat dipahami bahwa arah dan tujuan dari pengendalian penduduk adalah bahwa pengaturan kependudukan diarahkan kepada pengendalian kuantitas penduduk, pengembangan kualitas penduduk serta pengarahan mobilitas penduduk daerah. Sedangkan tujuan pengendalian kependudukan adalah untuk mewujudkan keserasian, keselarasan dan keseimbangan antara kuantitas, kualitas serta persebaran penduduk agar terjadi keserasian, keselarasan dan keseimbangan hubungan antara sesama manusia, hubungan manusia dengan lingkungan serta hubungan manusia dengan Tuhan (sebagaimana dalam konsep Tri Hita Karana).

Sebagaimana di perintahkan oleh Undang-Undang Nomor 23 tahun 2006, Pemerintah kabupaten/ kota berkewajiban dan bertanggung jawab menyelenggarakan urusan
Administrasi Kependudukan, yang dilakukan oleh bupati/walikota. Hal ini mempunyai makna bahwa Pemerintah Kota Denpasar mempunyai kewajiban dan bertanggungjawab dalam melakukan administrasi kependudukan. Bentuk kewajiban dan tanggung jawab Pemerintah Kota Denpasar tersebut dituangkan dalam Kebijakan-Kebijakan Tertib administrasi Kependudukan Kota Denpasar.

Mengenai penyelenggaraan administrasi kependudukan di Kota DenpasardiaturdalamPeraturanDaerah Kota Denpasar Nomor 5 Tahun 2014 tentang Penyelenggaraan Administrasi Kependudukan. Mengenai Penduduk pendatang dapat dilihat pengaturannya dalam Pasal 1 angka 30 yang menyatakan bahwa pindah dating penduduk adalah perubahan lokasi tempat tinggal untuk menetap karena perpindahan dari tempat yang lama ke tempat yang baru. Selanjutnya secara eksplisit mengenai penduduk pendatang diatur dalam Bab IV tentang Pendaftaran Penduduk bagian kedua tentang pendaftaran kependudukan paragraf 1 tentang pendaftaran pindah datang penduduk dalam wilayah Negara Republik Indonesia. Dalam Perda 5 tahun 2014 ini Sangat jelas diatur mengenai penduduk pendatang mulai dari kedatangan sampai proses pelaporan serta syarat-syarat yang harus dipenuhi. Adapun klasifikasi perpindahan penduduk sebagaimana diatur dalam Pasal 22 ayat (6) Jelas 
diatur perpindahan penduduk itu dapat terjadi dalam satu desa, antar desa, antar kecamatan, antar kabupaten atau kota dan antar provinsi.

Dalam Pasal 22 ayat (1) juga ada mengatur ketentuan bahwa penduduk yang bermaksud pindah yang masih dalam wilayah Negara Republik Indonesia wajib melapor kepada Dinas Kependudukan dan Pencatatan Sipil untuk mendapatkan surat keterangan pindah. Hal ini menunjukkan agar tidak terjadi perpindahan penduduk yang gelap dalam arti perpindahan penduduk yang tidak sah. Selanjutnya dalam Pasal 23 juga jelas diatur mengenai pelaporan pendaftaran perpindahan penduduk WNI yang harus dilengkapi dengan surat pengantar Kepala Dusun/Lingkungan, KK, KTP untuk mendapatkan surat keterangan pindah. Untuk lebih lanjut pengaturan penduduk pendatang Perda ini mendelegasikan dalam bentuk peraturan walikota.

Dasar kewenangan pemerintah Kota Denpasar dalam pengendalian penduduk pendatang juga dapat dilihat dalam Keputusan Walikota Denpasar Nomor 593 Tahun 2000 sebagaimana yang telah diubah menjadi Keputusan Walikota Denpasar Nomor 610 Tahun 2002. Pada dasarnya Keputusan ini mengatur mengenai prosedur dan tatacara pengaturan penertiban penduduk pendatang di Kota Denpasar dituangkan dalam Keputusan Walikota Denpasar Nomor 593 Tahun 2000 yang telah diubah menjadi Keputusan Walikota Denpasar Nomor
610 Tahun 2002. Dalam Pasal 1 Ayat (1) Keputusan Walikota menyatakan: "Setiap orang yang berasal dari luar Kota Denpasar dan ingin menjadi penduduk pendatang wajib memenuhi persyaratan tertentu". Selanjutnya persyaratan penduduk pendatang diatur dalam Pasal 1 Ayat (3)Keputusan Walikota yaitu :

a. Menyerahkan fotocopy KTP/ Surat Keterangan pindah.

b. Memiliki penjamin;

c. Surat Keterangan perjalanan dari Kepala Desa/Kelurahan daerah asal penduduk pendatang.

d. Keterangan keahlian/ kemampuan/keterampilan penduduk pendatang dan Desa/ Kelurahan dan atau Instansi yang berwenang di daerah asalnya.

e. Menyerahkan rekomendasi dari Banjar Adat atas nama Desa Pakraman setempat.

Setelah penduduk pendatang memenuhi persyaratan tertentu sesuai dengan Pasal 1 Ayat (3) maka keputusan itu dicatat oleh perangkat desa/Kelurahan setempat dalam register penduduk pendatang dan kemudian diberikan kartu identitas penduduk pendatang (KIPP) (Pasal 4 Ayat(1)). KIPP yang telah diberikan tersebut berlaku untuk jangka waktu 3 (tiga) bulan dan KIPP tersebut hanya dapat diperpanjang untuk jangka waktu paling lama 3 (bulan). Dalam hal KIPP telah diterima penduduk pendatang maka akan dikenakan biaya administrasi sesuai dengan Keputusan Desa/Kelurahan setempat. 
Dalam Keputusan Walikota Nomor 610 Tahun 2002 juga diatur mengenai tatacara dan prosedur penjamin, sebagaimana dinyatakan dalam Pasal 6 menyatakan bahwa kewajiban melalui Kepenjamin adalah:

a. Melaporkanpendudukpendatang yang dijamin kepada Bendesa Pakraman melalui Kelian Banjar Adat setempat.

b. Bertanggung jawab atas tingkah laku/perbuatan kepada pihak berwajib apabila penduduk pendatang yang dijamin melanggar ketentuan berlaku.

Terhadap tenggang waktu penjaminan maka diberikan jangka waktu 3 bulan, dan apabila dalam tenggang waktu itu, yang bersangkutan telah mendapat pekerjaan maka diwajibkan untuk surat keterangan jaminan bekerja. Selanjutnya KIPP hanya dapat diperpanjang dengan menggunakan dasar surat keterangan jaminan bekerja. Dan apabila tenggang waktu penjaminan ini telah berakhir dan yang bersangkutan belum mendapatkan pekerjaanmaka penjamin wajib memulangkan penduduk pendatang ke daerah asalnya.

Terkait dengan jumlah pungutan terhadap penduduk pendatang diatur dengan Keputusan Walikota Nomor 585 tahun 2002 tentang Perubahan Lampiran Keputusan Walikota Denpasar Tanggal 13 Desember 2001 Nomor 1002 tahun 2001 tentang
Standarisasi Pungutan/Sumbangan Kelurahan Di Kota Denpasar. Pernyataan itu sebagai berikut :

Laporan pendatang yang akan menjadi penduduk pendatang atau penduduk :

a. Jenis pungutan dari luar Denpasar dalam Propinsi Bali dikenakan biaya pungutan sebesar Rp. 50.000,-

b. Jenis pungutan dari luar Propinsi Bali dikenakan biaya pungutan sebesar Rp. 100.000,-.

Adapun pihak-pihak yang terlibat dalam pendaftaran penduduk pendatang di Kota Denpasar adalah sebagai berikut :

1. Persyaratan Penduduk Pendatang:

a. Fotocopy KTP/Surat Keterangan Pindah.

b. Memiliki Penjamin.

c. SuratKeteranganPerjalanan dari daerah asal.

d. Keterangan keahlian/ keterampilan.

e. Rekomendasi Banjar Adat atas nama Bendesa Adat.

2. Persyaratan Kewajiban Penjamin:

a. Melaporkan penduduk pendatang kepada Kelian Banjar Adat (paling lambat 2 X24 jam).

b. B ertanggungjaw ab atas segala perbuatan penduduk pendatang yang bersangkutan. 
c. Surat Pernyataan Penjamin.

d. Penjamin adalah warga setempat ber-KTP

Denpasar.

e. Memulangkan penduduk pendatang apabila tenggang waktu penjaminan telah berakhir/belum mendapat pekerjaan.

3. Tugas Klian Banjar Adat:

a. Mendukung dialog dengan penduduk pendatang bersama dengan penjamin.

b. Menerbitkan rekomendasi.

c. Melaporkan kepada kepala desa pakraman.

d. Memungut biaya administrasi sesuai dengan ketentuan yang berlaku.

4. Tugas Kepala Dusun/Kepala Lingkungan :

a. Mencatat dalam register penduduk pendatang

b. Membuat pengantar kepada kepala desa/Lurah untuk proses KIPP.

5. Tugas kepala desa/lurah:

a. Meneliti dan mencatat dalam register penduduk pendatang.

b. Biaya administrasi sesuai dengan ketentuan yang berlaku.

c. Menertibkan KIPP

d. Menertibkan penduduk pendatang bersama dengan Tim melibatkan Bendesa Pakraman.

6. Tugas Camat

a. Menertibkan penduduk pendatang bersama TIM melibatkan BPPLA.

b. Melaporkan penduduk liar yang terjaring ke instansi yang berwenang.

c. Membuat laporan kependudukan secara rutin setiap bulan.

Mendasarkan pada aturan-aturan hukum yang terkait dengan penduduk pendatang, bahwa Pemerintah Kota Denpasar berwenang dalam pengendalian penduduk pendatang.

\subsection{Bentuk keterlibatan Desa Pakraman dalamPengendalian Penduduk Pendatang di Kota Denpasar}

Berdasarkan pada prinsip otonomi daerah, yang menegaskan bahwa Pemerintah Daerah diberi kewenangannya untuk menyelenggarakan pemerintahnya. Memahami pemaknaan prinsip otonomi sebagaimana dikemukakan oleh logeman ${ }^{14}$ yaitu kebebasan dan kemandirian tetapi bukan kemerdekaan. Selanjutnya J. Wajong ${ }^{15}$ juga mengutarakan bahwa otonomi adalah kebebasan untuk memelihara dan memajukan kepentingan khusus daerah, dengan keuangan sendiri,

14 Y.W.Sunindhia, 1987,PraktekPenyelenggaran Pemerintahan di Daerah, Bina Aksara Jakarta, hlm. 35.

15 Lukman Hakim, 2012, Filosofi Kewenangan Organ Lembaga Daerah Perspektif Teori Otonomi \&Desetralisasi dalam Penyelenggaraan Pemerintahan Negara Hukum dan Kesatuan, Setara Press Malang hlm, 35. 
menentukan hokum sendiri dan pemerintahan sendiri. Lebih lanjut Lukman Hakim ${ }^{16}$ menyatakan bahwa Apabila otonomi diartikan sebagai segala tugas yang ada pada daerah atau dengan kata lain apa yang harus dikerjakan oleh pemerintah daerah, maka melekat kewenangan yang meliputikekuasaan, hak atau kewajiban yang diberikan kepada daerah dalam menjalankan tugasnya.

Mendasarkan pada kewenangan Pemerintah Kota Denpasar dalam pengendalian penduduk pendatang yaitu mendasarkan pada Keputusan Walikota Denpasar Nomor 593 Tahun 2000 sebagaimana yang telah diubah menjadi Keputusan Walikota Denpasar Nomor 610 Tahun 2002, memberi kewenangan pada desa pakraman untuk berpartisipasi dalam pengendalian penduduk pendatang. Dasar yuridis keterlibatan desa pakraman dalam pengendalian penduduk pendatang di atur dalam Pasal 8 Keputusan Walikota Denpasar Nomor 610 Tahun 2002 dengan ketentuan sebagai berikut :

(1) Bendesa pakraman diberikan kewenangan melakukan pembinaan dan pengawasan/ pengendalian terhadap keberadaan penduduk pendatang yang berada di wilayahnya.

(2) Bendesa pakraman dalam melaksanakan kewenangannya dilaksanakan oleh perangkat Banjar Adat dimana penduduk

16 Ibid, hlm.37. pendatang dimaksud berada.

(4)

Memahami Pasal 8 di atas bahwa desa pakraman diberi kewenangan dan terlibat dalam pengendalian penduduk pendatang yang dalam konteks ini dilaksanakan oleh banjar adat sebagai garda terdepan yang menyaring penduduk pendatang.

Keterlibatan Desa pakraman dalam pengendalian penduduk pendatang juga dapat dilihat dalam Peraturan Daerah Propinsi Bali Nomor 10 Tahun 1998 dalam BAB VI tentang Peran Serta Masyarakat yang ditegaskan dalam Pasal 11 ayat (2) yaitu " bahwa Peran serta yang dimaksud adalah peran serta masyarakat baik itu lembaga swadaya ataupun Organisasi masyarakat termasuk pasuka-dukaan Banjar, pihak swasta dan perorangan secara sukarela. Perda 3 tahun 2001 tentang Desa Pakraman, juga mengatur tentang peran serta dalam administrasi kependudukan. Peran serta tersebut terdapat dalam Pasal 5 huruf $d$ yang menyatakan "salah satu tugas desa pakraman adalah ...bersamasama Pemerintah melaksanakan pembangunan di segala bidang...". Kemudian Pasal 6 menyatakan bahwa salah satu wewenang desa pakraman adalah “...turut serta menentukan setiap keputusan dalam pelaksanaan pembangunan yang ada di wilayahnya...". Ketentuanketentuan tersebut diatas semakin mempertegas dan menguatkan 
pelibatan Desa Pakraman dalam kegiatan pembangunan termasuk dalam hal penanganan penduduk pendatang.

Selanjutnya keterlibatan

Desa pakraman juga dapat dilihat dalam Instruksi Gubernur Nomor 12 tahun 1992 tentang Pengawasan dan Peningkatan Tertib Administrasi Kependudukan Propinsi Daerah Tingkat I Bali yaitu “ . ...tetap berupaya meningkatkan partisipasi masyarakat dalam mewujudkan tertib administrasi kependudukan".

Selain diatur dalam Peraturan Daerah, Keterlibatan Desa Pakraman dalam Pengendalian penduduk Pendatang diatur secara jelas dalam Keputusan Walikota No.593 tahun 2000, khususnya Bab III Pasal 9 tentang Peranan Desa Adat. Ketentuan ini diubah dengan Keputusan Walikota Nomor 610 Tahun 2002, Pasal 8 yang memberikan kewenangan dalam kependudukan yang secara rinci diatur dalam beberapa ayat diantaranya :

(1) Bendesa Pakraman diberikan kewenangan melakukan pembinaan dan pengawasan/ pengendalian terhadap keberadaan penduduk pendatang yang berada di wilayahnya.

(2) Bendesa Pakraman dalam melaksanakan kewenangannya dilaksanakan oleh perangkat Banjar Adat dimana penduduk pendatang dimaksud berada.

(3) Kewenangan perangkat banjar adat dimaksud ayat (2) pasal ini adalah memberikan keterangan atau rekomendasi mengenai keberadaan penduduk pendatang diwilayahnya, sebagaimana dimaksud pasal 1 ayat (3) huruf e dan keterangan dimaksud merupakan persyaratan untuk dapat berlangsungnya proses administrasi kependudukan.

(4) Banjar Adat dalam melaksanakan kewenangan dimaksud ayat (3) dilaporkan kepada Desa Pakraman yang mewilayahi nya.

Pelibatan Desa Pakraman dalam pengendalian penduduk pendatang oleh Pemerintah Kota Denpasar juga tertuang dalam Kesepakatan Bersama antara Forum kepala Desa/Lurah Kota Denpasar dengan Parum Bendesa Desa Pakraman Kota Denpasar Tentang Penertiban Penduduk Pendatang Di Kota Denpasar. Nomor : 11/FK/ IX/2002 (Pihak Pertama) yaitu Forum Kepala Desa/Lurah dan Nomor : 003/ PBDA/IX/2002 (Pihak Kedua) yaitu Parum Bendesa Pakraman. Dalam kesepakatan bersama ini terdapat 4 (empat) Pasal yaitu :

Pasal 1 terdapat dua (2) point :

1. Pihak pertama dengan pihak kedua secara bersama melakukan Pembinaan dan Penertiban Penduduk Pendatang.

2. Pihak kedua wajib mendata Penduduk Pendatang.

Selanjutnya dalam Pasal 2 disebutkan bahwa pihak pertama dan kedua berkoordinasi untuk tercapainya 
daya guna dan hasil guna yang optimal. Dalam Pasal 3 dinyatakan bahwa dalam pendataan penduduk pendatang dapat memungut uang pendaftaran sesuai dengan pararem desa pakraman dan penggunaan hasil pungutan itu diatur melalui paruman desa adat/desa pakraman setempat.

Berdasarkan pada pemahaman Pasal 3 bahwa desa pakraman diberikan otoritas untuk memungut uang pendaftaran penduduk pendatang sesuai dengan pararem, maka Parum Bendesa Desa Pakraman Kota Denpasar membuat Keputusan Manggala Parum Bendesa Desa Pakraman Kota Denpasar Nomor : 005/ PBDA/XI/2002 tentang Standarisasi pungutan Desa Pakraman Atas Biaya Administrasi Penduduk Pendatang Di Kota Denpasar. Standarisasi pungutan Desa Pakraman atas biaya administrasi Penduduk Pendatang terdapat dalam Pasal 1 yaitu penduduk yang berasal dari luar Denpasar dalam Propinsi Bali dipungut sebesar Rp. 50.000,(lima puluh ribu rupiah) dan penduduk yang berasal dari luar Propinsi Bali maka dipungut Rp. 100,000,- (seratus ribu rupiah). Pengalokasian pungutan diatur dalam pasal 2 yaitu " $20 \%$ diperuntukkan Desa Pakraman, $20 \%$ diperuntukkan Banjar yang bersangkutan, $60 \%$ diperuntukkan biaya operasional petugas dan administrasi blanko-blanko.

Terkait dengan bentuk riil keterlibatan desa pakraman dalam pengendalian penduduk pendatang dapat dilihat dalam awig-awig desa pakraman padangsambian. Dalam Pawos 6 awig-awig desa pakraman padangsambian ditentukan " Indik karma tamiu lan tamiu kadabdab olih banjar pakraman soangsoang”. Menindak lanjuti ketentuan Pasal 6 tersebut Bendesa Pakraman menetapkan keputusan desa pakraman Nomor : 05 / KEP / DP.Pds / 14 tentang Kontribusi Biaya Ketertiban dan Keamanan Sosial di Wilayah Desa Pakraman Padangsambian. Apabila dilihat dari konteks lahirnya Keputusan Bendesa Pakraman Padangsambian ini menunjukkan bahwa telah ada koordinasi pihak desa pakraman dengan pihak desa dinas untuk bekerja sama dalam pengendalian penduduk pendatang.

Hal ini dapat dilihat adanya rapat koordinasi Bendesa Pakraman Padangsambian Kelihan Majelis Paruman Krama Desa Pakraman Padangsambian dengan Lurah Padangsambian, Kepala Desa Padangsambian Kelod, Kepala Desa Padangsambian Kaja, Kepala Desa Tegal Harum, Kelihan Banjar, Kepala Lingkungan, Kepala Dusun, Babinsa dan Babhinkamtibmas pada hari Rabu, 18 Juni 2014 di Kantor Lurah Padangsambian yang menghasilkan keputusan desa pakraman Nomor : 05 / KEP / DP.Pds / 14 tentang Kontribusi Biaya Ketertiban dan Keamanan Sosial di Wilayah Desa Pakraman Padangsambian. Berdasarkan hasil rapat tersebut menghasilkan 6 poin: 
1. Penerimaan krama tamiu dan tamiuyangbarudatangdantinggal menetap maupun sementara dalam jangka waktu tertentu di Kelurahan Padangsambian, Desa Padangsambian Kaja, Desa Padangsambian Kelod dan Desa Tegal Harum yang menjadi bagian wilayah Desa Pakraman Padangsambian wajib:

a. membawa persyaratan surat pindah dari daerah asal;

b. memperoleh KIPPS dan STPPTS sebagai persyaratan administrasi penduduk baru yang dikeluarkan dari Desa dan Kelurahan di wilayah Desa Pakraman Padangsambian;

c. memperoleh rekomendasi pindah sebagai krama tamiu dan tamiu dari Bendesa Desa Pakraman Padangsambian dengan menunjuk pelaksana teknis kepada Kelihan Banjar.

2. Untuk menjamin ketertiban dan keamanan sosial-nya bagi krama tamiu dan tamiu yang baru datang dan tinggal menetap maupun sementara dalam jangka waktu tertentu, dikenakan kontribusi biaya sebesar Rp. 100.000,- (seratus ribu rupiah) bagi penduduk pendatang luar Provinsi Bali dan penduduk pendatang luar Denpasar dalam Provinsi Bali sebesar Rp 25.000,- (dua puluh lima ribu rupiah). Penggunaan kontribusi biaya tersebut akan diatur dan disumbangkan sebagian kepada Desa dan Kelurahan yang ada di wilayah Desa Pakraman Padangsambian sebagai wujud sinergi dan koordinasi dalam pengendalian kependudukan (terlampir dalam Keputusan).

3. Pengenaan kontribusi biaya sebagaimana dimaksud poin kedua, dibayar pada saat krama tamiu dan tamiu yang telah memenuhi kelengkapan persyaratan administrasi kependudukan mendaftar di Kelihan Banjar yang melaksanakan rekomendasi Bendesa Pakraman Padangsambian..

4 Terhadap Dusun/Lingkungan/ Banjar yang belum memiliki Kelihan Banjar definitif, rekomendasi Bendesa Desa Pakraman Padangsambian dapat dilaksanakan oleh Kelihan Banjar Pakraman terdekat..

5. Apabiladikemudianhariterdapat kekeliruan dalam penerbitan Keputusan ini akan dilakukan perubahan sebagaimana mestinya.

6. Keputusan ini berlaku sejak tanggal ditetapkan.

Dalam awig-awig Banjar Adat Robokan Desa Adat Kerobokan juga mengatur mengenai penduduk pendatang sebagaimana terdapat dalam Pawos 4 kaping 2 huruf ca menentukan : 
Krama Padgata Kala, inggih punika karma sane magama Hindu utawi magama siyosan, sane during pastika ajeg jenek ring wawidangan Banjar Robokan, saha kacacah ring pipil karma padgata kala Banjar Robokan.

Selanjutnya dalam dalam pawos 6 awig-awig tersebut juga ditentukan tentang kewajiban krama padgata kala yiatu : "Swadarma Krama Banjar Padgata Kala :

- $\quad$ Tinut ring daging awig-awig puniki, utamanyane indik karma padgata kala.

- Nawur Pacingkrem manut pararem Banjar Adat Robokan.

Hal di atas dapat dipahami bahwa dalam awig-awig Banjar Adat Robokan Desa Pakraman Kerobokan juga diatur mengenai krama tamiu dan tamiu (penduduk pendatang). Bahwa penduduk pendatang harus patuh terhadap isi awig-awig dan membayar urunan sesuai dengan pararem Banjar Adat Robokan.

Untuk mengetahui besaran urunan yang dimaksud dalam awigawig Banjar Adat Robokan dapat dilihat dalam Pararem Awig-Awig Banjar Adat Robokan. Dalam Pawos 5 Pararem tersebut menentukan bahwa "karma saking dura Negara banjar Robokan sane jenek saha maderbe umah/jero/griya utawi nyewa umah/ tanah sekirangnyane 5 (limang) warsa ring wewidangan Banjar Robokan patut mekrama banjar dinas, tata caranyane manut ring uger-uger Guru
Wisesa lan pararem Banjar Adat Robokan inggih punika nawur dana Yatra ageng ipun Rp. 1.000.000,- (a yuta rupiah)." Ketentuan ini dapat dimaknai bahwa penduduk pendatang yang tinggal kurang dari 5 tahun di banjar adat Kerobokan membayar iuran 1.000.000, (satu juta rupaiah).

Terkait dengan kewajiban penduduk pendatang yang tinggal di banjar adat Kerobokan yaitu sebagaimana diatur dalam Pawos 6 kaping 3 yang menentukan :

Swadarma Krama Banjar Padgata kala “:

Nawur pacingkreman manut pararem Banjar Adat Roboksn inngih punika :

1. Nawur pacingkreman ageng ipun Rp. 5.000,- (limang tali rupiah) nayabaran a bulan.

2. Krama Padgata kala saking dura Bali patut meduwe KIPS lan nawur Rp. 100.000 (satus tali rupiah) adiri nyabaran 3 (tigang) bulan sane keepah dados kalih inngih punika ring banjar Robokan Rp. 50.000,(seket tali rupiah) lan ring desa Dinas Rp. 50.000,- (seket tali rupiah).

3. Krama Padgata Kala saking Bali sane meduwe KTP ring luar Kota Denpasar patut meduwe KIPS lan nawur Rp. 25.000,(slae tali rupiah) a nyabaran 6 (enem) bulan sane keepah dados kalih inggih punika ring banjar Robokan Rp. 20.000,- (duang 
dasa tali rupiah) lan ring desa dinas Rp. 5.000,- (limang tali rupiah)

4. Krama Padgata Kala sane kari ngeranjing nenten keni dana KIPS lain iuran.

Mendasarkan pada awig-awig Desa Pakraman Padangsambian dan Awig-awig Banjar adat Robokan Desa Adat Kerobokan, jelas ada pengaturan mengenai penduduk pendatang dan tata cara menangani penduduk pendatang. Salah satu yang dapat dilakukan oleh desa pakraman dan banjar adat adalah dengan mengenakan iuran bagi penduduk pendatang yang tinggal di wilayah desa adat dan banjar adat. Hal ini juga perlu dipahami bahwa bentuk keterlibatan desa pakraman dan banjar adat dalam pengendalian penduduk pendatang adalah dengan membuat aturan yang jelas tentang penduduk pendatang dan membuat pararem yang dengan jelas juga mengatur tata cara pengaturan penduduk pendatang. Tata cara tersebut juga mengatur secara jelas tentang berapa iuran yang akan dikenakan pada penduduk pendatang.

Dengan adanya aturan yang memberi kewenangan pada desa pakraman melalui banjar adat untuk ikutsertadalampengendalianpenduduk pendatang dan itu dituangkan dalam pararem banjar adat. Ini menunjukan bahwa salah satu bentuk keterlibatan desa pakraman dalam pengendalian penduduk pendatang.

Seturut dengan ketentuan yang telah tertuang dalam awig-awig desa pakraman serta pararem desa pakraman di atas, nampaknya senada dengan keputusan Majelis Utama Desa Pakraman (MDP) Bali Nomor; 050/Kep/Psm-1/MDP Bali/III/2006, Jumat 3 Maret 2006,yang menjelaskan beberapa point yaitu :

1. Penduduk Bali berdasarkan agama yang dianut dantempatnya berdomisili, dikelompokkan menjadi tiga yaitu : krama desa (penduduk beragama Hindu dan mipil atau tercatat sebagai anggota di desa pakraman); krama tamiu (penduduk yang beragama Hindu dan tidak mipil atau tercatat sebagai anggota desa pakraman); dan tamiu (penduduk non-hindu dan bukan anggota desa pakraman).

2. Masing-masing golongan penduduk tersebut berlaku swadarma (kewajiban) yang berbedaterhadapdesapakraman. Perbedaan itu hendaknya memberikan kenyamanan kepada ketiga golongan penduduk tersebut.

3. Krama tamiu dan tamiu berdasarkan aktivitasnya di desa pakraman, dapat dibedakan menjadi dua yaitu : a) krama tamiu dan tamiu yang hanya berdomisili di desa pakraman; dan b) Krama tamiu dan tamiu yang berdomisili dan atau membuka usaha di desa pakraman.

Keputusan Majelis Desa 
Pakraman ini dapat juga dipahami bahwa setiap penduduk pendatang (karma tamiu dan tamiu) mempunyai kewajiban berbeda apabila tinggal di wilayah desa pakraman. Perbedaan kewajiban tersebut dituangkan dalam awig-awig dan pararem desa pakraman. Lebih lanjut keputusan Majelis Desa Pakraman tersebut juga menyatakan bahwa pertama, karma tamiu wajib menciptakan kesukertan (kedamaian) desa pakraman bersama-sama dengan krama desa baik yang menyangkut parahyangan (keyakinan), pawongan (aktivitas kemanusiaan) serta palemahan (kelestarian lingkungan alam), kedua, bahwa kewajiban itu dituangkan dalam bentuk sikap saling menghormati disertai urunan dan ayah-ayahan(wajib kerja) yang dapat diganti dengan uang dan jumlah keduanya tidak lebih dari $10 \%$ dari pada kewajiban karma desa, serta dapat memberikan dana punia (sumbangan sukarela).

Selanjutnya dalam keputusan MUDP tersebut juga mengatur kewajiban tamiu (kraman non hindu) yaitupertama, tamiuwajibmenciptakan kesukerta desa pakraman bersamasama karma desa dan karma tamiu dan aktivitas lainnya yang berhubungan dengan kemanusiaan dan kelestarian lingkungan alam, sepanjang tidak terkait langsung dengan parhyangan (keyakinan beragama menurut ajaran hindu). Kedua, kewajiban tersebut dituangkan dalam bentuk sikap saling menghormati disertai dengan urunan dan ayah ayahan yang dapat diganti dengan uang dan jumlah keduanya tidak lebih dari pada $30 \%$ dari pada kewajiban karma desa serta dapat memberikan dana punia (sumbangan sukarela).

Dengan demikian bahwa desa pakraman yang ada di Kota Denpasar, perlu memperhatikan ketentuanketentuan yang ada dalam keputusan Majelis Desa Pakraman, sehingga ada kesatuan tafsir terkait kewajiban karma tamiu dan tamiu yang berdomisili di Kota Denpasar.

\section{KESIMPULAN}

Berdasarkan uraian di atas, dapat disimpulkan sebagai berikut :

1. Bahwa kewenangan Pemerintah Kota Denpasar dalam pengendalian penduduk pendatangadalahdidasarkanpada kewenangannya sesuai dengan Undang-Undang Dasar Negara Republik Indonesia Tahun 1945 mengatur mengenai penduduk yaitu dalam Pasal 26 ayat (2) dan ayat (3) yang pemahamannya bahwa mengenai warga negara dan penduduk diatur dengan Undang-undang. Selanjutnya dasar kewenangannya dapat juga dilihat dalam pasal 12 huruf $\mathrm{F}$ Undang-Undang Nomor 23 Tahun 2014 tentang Pemerintahan Daerah yang menyatakan bahwa dalam bidang Administrasi Kependudukan dan Pencatatan Sipil merupakan 
urusan wajib. Pengaturan Administrasi Kependudukan juga dapat dilihat dalam lampiran huruf L khususnya dalam bidang Administrasi Kependudukan dan PencatatanSipil.Undang-undang Nomor 24 Tahun 2013 Tentang Perubahan atas Undang-Undang Nomor 23 Tahun 2006 tentang Administrasi Kependudukan memberi dasar kewenangan untuk mengatur administrasi kependudukan termasuk di dalamnya pengaturan penduduk pendatang. Pengaturan penduduk pendatang dalam tataran loka juga diatur dengan Peraturan Daerah Nomor 10 Tahun 1998 tentang Pengendalian Kependudukan. Dalam pasal 9 Peraturan Daerah Provinsi Bali Nomor 10 Tahun 1998 dinyatakan bahwa Gubernur menetapkan kebijaksanaan untuk mengarahkan kualitas penduduk dengan memperhatikan nilainiali agama, etika dan sosial budaya. Selanjutnya dasar kewenangan Kota denpasar dalam pengendalian penduduk Pendatangadalahdidasarkanpada Peraturan Daerah Nomor 5 Tahun 2014 tentang Penyelenggaraan Administrasi Kependudukan, Selanjutnya pengendalian penduduk pendatang lebih rinci dapat dilihat dalam Keputusan Walikota Denpasar Nomor 593 Tahun 2000 sebagaimana yang telah diubah menjadi Keputusan Walikota Denpasar Nomor 610 Tahun 2002. Terkait dengan pungutan terhadap penduduk pendatang dapat dilihat dalam keputusan Walikota Nomor 585 tahun 2002 tentang Perubahan Lampiran Keputusan Walikota Denpasar Tanggal 13 Desember 2001 Nomor 1002 tahun 2001 tentang Standarisasi Pungutan/ Sumbangan Kelurahan Di Kota Denpasar.

2. Bentuk keterlibatan desa pakraman dalam pengendalian penduduk pendatang di Kota Denpasar adalah mendasarkan pada Keputusan Walikota Nomor 593 Tahun 2000 sebagaimana yang telah diubah menjadi Keputusan Walikota Denpasar Nomor 610 Tahun 2002, memberi kewenangan pada desa pakraman untuk berpartisipasi dalam pengendalian penduduk pendatang, yang secara rinci diatur mengenai kewenangan desa pakraman dalam melakukan pengawasan penduduk pendatang. Pemahaman terhadap ketentuantersebutditindaklanjuti oleh desa pakraman di Kota Denpasar. Sebagaimana telah dijelaskan dalam pembahasan yang menyatakan bahwa dalam awig-awig Banjar Adat Robokan Desa Adat Kerobokan juga mengatur mengenai penduduk pendatang. Besaran urunan 
dalam ketentuan awig-awig Banjar Robokan khususnya dalam pararemnya adalah ketentuan ini dapat dimaknai bahwa penduduk pendatang yang tinggal kurang dari 5 tahun di Banjar Adat Robokan membayar iuran 1.000.000, (satu juta rupiah). Selain itu ada kewajiban lain yang harus dipenuhi oleh penduduk pendatang yaitu membayar uang urunan yang bervariasi yiatu Rp5000,- setiap bulan, Rp100.000, setiap tiga bulan yang mempunyai KIPS dan membayar 25.000,- bagi penduduk yang telah mempunyai KTP. Dengan adanya aturan yang memberi kewenangan pada desa pakraman melalui banjar adat untuk ikut serta dalam pengendalian penduduk pendatang dan itu dituangkan dalam pararem banjar adat. Ini menunjukkan bahwa salah satu bentuk keterlibatan desa pakraman dalam pengendalian penduduk pendatang.

\section{DAFTAR PUSTAKA}

\section{Buku}

Bambang Waluyo, 1991, Penelitian Hukum Dalam Praktek, Sinar Grafika, jakarta.

Bambang Sunggono, 2003, Metodelogi

Penelitian Hukum. Rajawali Pers Jakarta.

Indroharto, 1993, Usaha memahami Undang-Undang tentang
Peradilan Tata Usaha Negara, Pustaka Harapan, Jakarta.

Jum Anggriani, 2012, “ Hukum Administrasi Negara", Graha Ilmu, Yogyakarta

Lukman Hakim, 2012, Filosofi Kewenangan Organ Lembaga Daerah Perspektif Teori Otonomi \& Desentralisasi dalam Penyelenggaraan Pemerintahan Negara Hukum dan Kesatuan, Setara Press Malang

Majelis Utama Desa Pakraman, 2010, Himpunan Hasil-Hasil Pesamuhan Agung III MDP Bali, Majelis Utama Desa Pakraman Bali, Dinas Kebudayaan Provinsi Bali.

Morris L. Cohen dan kent C. Olson, 2000, Legal Research In A Nutshell, Seventh Edition, ST. Paul, Minn, West Group.

Marhaendra Wija Atmaja, Gede "Politik Pluralisme Hukum dalam Pengakuan Kesatuan Masyarakat Hukum Adat dengan Peraturan Daerah", Disertasi Doktor, Program Doktor Ilmu Hukum Fakultas Hukum Universitas Brawijaya, Malang, 2012.

Oka Parwata, A A Gede, 2003, "Pola Hubungan Antara Desa Dinas dengan Desa Adat dalam Penanganan Penduduk Pendatang di Kecamatan Ubud Kabupaten Gianyar", Kerjasama Lembaga Penelitian dengan BAPPEDA Kabupaten Gianyar. 
Philipus M. Hadjon, et.al, 2011, Pengantar Hukum Administrasi Indonesia, Introduction to the Indonesian Administrative law, Gadjah Mada University Press, Yogyakarta.

Prajudi Atmosudirjo,1994, Hukum Administrasi Negara, Cetakan Kesepuluh, Ghalia Indonesia, Jakarta.

Pitana, I Gde, 2000, Kuta Cermin Retak Pariwisata Bali, Upada Sastra.

Prajudi Atmosudirjo,1994, Hukum Administrasi Negara, Cetakan Kesepuluh, Ghalia Indonesia, Jakarta.

Peter Mahmud Marzuki, 2005, Penelitian Hukum, Cetakan ke1, Kencana, Jakarta

Ridwan HR, 2006, Hukum Administrasi Negara, PT. Raja Grafindo Persada, Jakarta.

Sadjijono, H 2011, Bab- Bab Pokok Hukum Administrasi, Cetakan II, Edisi II, Laksbang Pressindo, Yogyakarta

Soepomo, 2000, Bab-Bab Tentang

Hukum Adat, Pradnya Paramita Jakarta.

Soerjono Soekanto, 1986, Pengantar

Penelitian Hukum, Universitas Indonesia (UI) Press), Jakarta dan Sri Mamuji,

1986, Penelitian Hukum

Normatif suatu Tinjauan Singkat, CV Rajawali Jakarta.

Sudantra, I Ketut, 2001, "Pola Penyelesaian Persoalanpersoalan Hukum oleh Desa
Adat", Dinamika Kebudayaan, Vol III No. 1, Lembaga Penelitian Universitas Udayana.

$\begin{array}{cr}\text { Serta masyarakat } & \text { Palam }\end{array}$ Pengendalian Kependudukan khususnya Penduduk Pendatang Di Kecamatan Kuta Utara Kabupaten Badung.

Saily Falk Moore, 2001, Hukum dan Perubahan Sosial: Bidang Sosial Semi Otonom sebagai suatu topic studi yang Tepat dalam TO Ihromi, antropologi Hukum Sebuah Bunga Rampai, Yayasan Obor Indonesia.

W. Sunindhia, 1987, Praktek Penyelenggaraan Pemerintahan di Daerah, Bina Aksara Jakarta.

Tim Pusat Studi Hukum Adat,2001, Kedudukan Desa Pakraman Dalam Penyelenggaraan Pemerintahan Desa setelah berlakunya UU No. 22 Tahun 1999 di Kabupaten Gianyar, Laporan Penelitian, Denpasar Kerjasama antara BAPPEDA Kabupaten Gianyar dan Lembaga Penelitian Universitas Udayana. Talizuduhu Ndraha, 1986, Pembangunan Masyarakat, Departemen Pendidikan dan Kebudayaan

Windia P dan Ketut Sudantra, 2006, Pengantar Hukum Adat Bali, Lembaga dokumentasi dan publikasi Fakultas hukum Universitas Udayana. 
Yudhi Setiawan, 2009, Instrumen

Hukum campuran (gemeenscapelijkrecht) dalam Konsolidasi Tanah, PT. Raja Grafindo Persada, Jakarta

\section{Peraturan}

\section{Perundang-Undangan}

Undang-Undang Nomor 23 Tahun 2006 tentang Administrasi Kependudukan.

Undang-undang Nomor 24 Tahun 2013 Tentang Perubahan atas Undang-Undang Nomor 23 Tahun 2006 tentang Administrasi Kependudukan

Peraturan Daerah Propinsi Bali

Nomor 10 Tahun 1998 tentang Pengendalian Kependudukan Dalam Wilayah Propinsi Daerah Tingkat I Bali.

Peraturan Daerah Nomor 5 Tahun 2014 tentang Perubahan atas Peraturan Daerah Kota Denpasar Nomor 6 Tahun 1996 tentang Penyelenggaraan Pendaftaran Penduduk dalam Kerangka Sistem Informasi manajemen Kependudukan (SIMDUK).

SK Walikota Denpasar Nomor 593

Tahun 2000 tentang Penertiban Penduduk Pendatang di Kota Denpasar.

SK Walikota Denpasar Nomor 610 Tahun 2002 tentang Perubahan Keputusan Walikota Denpasar nomor 539 Tahun 2000 Tentang Penertiban Penduduk Pendatang.
SK Walikota Denpasar Nomor 585 Tahun 2002 tentang Perubahan Lampiran tentang Keputusan Walikota Denpasar Tanggal 13 Desember 2001 Nomor 1002 Tahun 2001 tentang Standarisasi Pungutan Desa/ Sumbangan Kelurahan di Kota Denpasar.

Kesepakatan Bersama antara Forum Kepala Desa /Lurah Kota Denpasar dengan Parum Bendesa Pakraman Kota Denpasar tentang Penertiban Penduduk Pendatang di Kota Denpasar.

SK Manggala Parum Bendesa Desa Pakraman Kota Denpasar Nomor 005/PBDA/XI/2002 tanggal 18 Nopember 2002 tentang Standarisasi Pungutan Desa Pakraman atas Biaya Administrasi Penduduk Pendatang di Kota Denpasar.

Awig-Awig Banjar Kaja, Desa Adat Pakraman Sesetan, 2014.

Awig-Awig Desa Pakraman Padang Sambian tahun 2007.

Awig-Awig Banjar Adat Robokan Tahun 2014.

Pararem Awig-Awig Banjar Adat Robokan 2014. 